\title{
CURRENT METHODS OF PROFESSIONAL MANAGEMENT OF THE HEAD OF AN EDUCATIONAL INSTITUTION
}

\author{
GALYNA MYKHAYLYSHYN, OKSANA YAKYMIV
}

\begin{abstract}
The article substantiates current actual technologies of the activity of the head of the educational institution. The fundraising competence of the head of the educational institution as the newest component of managerial competencies related to the requirements of time and changes in the guidelines of the society in order to implement a fundraising system in the innovative strategic management of the educational institution is grounded in the article. The general theoretical questions concerning the emission of knowledge about the essence of fundraising in the education system and the concept of "fundraising" are specified. The emphasis is on conducting an effective fundraising campaign to raise funds for the implementation of socially significant and scientific projects, resource search for a quality educational process.
\end{abstract}

Keywords: fundraising, fundraising competence, entrepreneurial attribute, educational service, endowment fund of trustee council, budgeting of educational institution, strategic management, financial autonomy of educational institution, specificity of management concepts.

Formation of new approaches to the management of Ukrainian education in its reformation period is to ensure the effectiveness of the mission of schools, obliges us to turn to the experience of European countries (Poland, Finland, Canada and others) and the United States, where the development of the theory and practice of good school governance took place under the influence of practice of management in educational institutions. They identified their market com petitiveness and dependence by defining business sign making, as many educational institutions in practice unconsciously are engaged in business activities in an effort to ensure their school by necessary resources for implementing financial capacity of reaching its goals or meet statutory requirements, practicing social entrepreneurship. Professor of Jagiellonian University T. Vavak emphasizes the transformation of educational institutions into the entrepreneurial education services, the management in which is implementing under the laws of business administration. He distinguishes its impact on the increasing of demands for a principal, and to all school staff, he says: "Entrepreneurial educational institution is his feature, not a kind, as the institution is not a company". It will be enterprising if its employees are enterprising and are able to finance its development. The main incentive of school's development is its active marketing. Its head must be a manager, an economist, a model of innovation, creativity, ethical behavior, personal incentives to work in favor of an educational institution, and its self improvement.

Nowadays, the popular research of Americans Ken Robinson and Lou Aronica about the revolution at school, that will "completely change the world" under the eloquent title "The School of Future", is consonant with the ideology of Ukrainian government and focuses on the model of American Association of Directors Breaking Ranks Framework, which motto is "To break the system and be ahead!". This is a participatory personalization of school and its head development, which focuses on 
problems of changes and innovations that lead to the development of educational institution, which depends on the activities and incomes of all participants of educational process and compares the similarity of a school and a company, which develops key components of educational culture. This process depends on the development of new ideas and desire of the head to try its entrepreneurial approaches at school managing through three developmental trends, which separate its economical (fundraising) competence. They are:

- awareness of the importance of material and technological base of educational institution and the process of raising funds and providing them services;

- increasing of attention not only to the organizational culture of the head but also to various forms of democratic governance and use the basics of management in its implementation;

- participatory democratic partnership of workers and local authorities that are formed and operate at school in the accumulation, resource allocation and implementation of management functions of a manager.

Thus, the economic component is crucial in a system of professional management competencies of head of educational institution. It forms not only skills of drafting school budget request but also a budget management in general.

Summarizing a foreign experience, should also refer to the experience of Ukrainian immigrants philanthropists (Gavrylyshyn B., Antonovych O.) and to many compatriots - researches in the field of education and science of 19-20 century on multichannel financing of educational institutions, which has always existed, although the problem of educational fundraising in Ukraine, as a separate problem, hadn't been studied before. The current state of democratic society distinguishes nationwide volunteerism, philanthropy and charitable activities that have become large-scale and have national character and not inferior in its uniqueness with foreign analogues. This shows that Ukraine has entered into a new step of development of the national fundraising that requires the isolation of the term Ukrainian internal fundraising, which is still treated as a charity.

The main goal of our research is to show the possibilities of initiative management in education system that can be implemented by certain techniques, principles of activites, financial and strategic methods depending on situations. We are sure that quality changes will take place in stage-by-stage reformation of educational space, where a public-state management will relay on a school -based management, that already is legislatively declared in the project of Law in Ukraine "Education", which are :

- the transfer of education authorities thier powers directly to every school (to the head that will manage the educational institution and will bear the responsibility for educational, financiallyeconomic and other activity);

- financial autonomy of school (it is yet declarative because of the absence in the manning table managers and accountants);

- economic competense is one of leading, newest, extremely necessary competenses of modern director as a top-manager.

Fundraising activity, is not already something new in education of Ukraine, however its formation as a system is only in the stage of research, because:

- legislative and normatively-legal acts of kindergarden and schols activity, were created in $90^{\text {th }}$, accordinly they need a new release;

- management education authorities did not give the status of legal entity to kindergarten, school and normatively-legal status of school is indefinite until now ;

- indicated in the legislative base budgetary independence of kindergarten, school, is not realized according to numerous normatively-legal limitations and to proper attitude of public and local authorities;

- garden, school, out-of-school institution - this is an organization (institution) that submits to the classic theory of economic management. Therefore a school management must take into account all "classic" functions and management ares, powers delegations etc. 
Accent on fundrising competence of educational leader as economic component in the professional competenses system, we assume that she will be the determinant in the innovative strategic planning process of development.

Education is undergoing a period of reform and only a new leader can be competitive specialist. Becouse of the ability to strategic think, to predict the future, to introduce innovations.

The principles and types of fundraising activity we can understand only through the corporate fundraising team of professionals from the head to the child. The effectiveness of fundraising activity dependes on the cooperation of educational institution with:

- state institutions through the implementation of programs;

- benefactors, patrons, sponsors;

- donors through the projects;

- parents;

- NGOs (both external and internal), common project activities;

- activity of the leader and his personal participation in the multichannel and multi fundraising activities;

- effective system of management in the educational institution.

Our study showed that schools made the projects, but did not identify this process as fundraising through:

- often used the term "charitable funds" than a process of fundraising;

- the non-use of mechanisms for financial accounting because of the lack of independent accounting units in the staff;

- haphazard or inconsistent process of raising funds, investments that is based largely on the social impact of it (project description but not its funds) etc.;

- heads of educational institutions have no proper education on management;

- insufficient strategic vision of institution development and its layout based on current strategies and more.

The project joint activities of schools with non-governmental (public) organizations requires fundraising competence of the head of educational institution. Knowledge and skills of project development, execution of the project application, communication with donors, patrons, sponsors and others.

However, for Ukrainian NGOs fundraising activity is systemic, they are constantly involved in grant competitions that coordinate international organizations and technical assistance programs, domestic and foreign charitable foundations.

Therefore, the school can receive funding for the project from foundations, which are divided into state, intermediary, private, independent, associates, local, etc. State funds - state institutions financed from the budget of the state, intermediary funds - NGOs financed by public or private funds which allocate finances. They usually funded programs that do not go beyond their country and not pay for work of foreigners. Such funds usually existe on dividends from the inlaid capital and have a clear list of priorities.

A word "project" is used mostly as "an educational project technologies". But we understand a project under this term as an instrument for changes. World Bank gives the following interpretation of this word "project - a set of interrelated activities designed to achieve set goals over a given period and the budget with clear objectives". The project that has a clearly defined beginning and the end, specific goals and objectives, cources to the real results. Project work requires financial and time costs, provides the use of various resources. The project always has not only the financial result but the social.

Grant is the main form of financing, that realize international organizations. Grant is charity payment (donation) provided by donor (Fund), for the implementation of the non-profit project or program. For terms of frequency the competitive grant programs are divided into single, cyclical and permanent. Every Fund uses its own procedure and tipe of cooperationt. Typically, they use special application forms that are open publicly to the society. 
Factors that have possitive influence on fundraising are: a positive image of the organization; experience with other charitable organizations, the experience of scientific-business cooperation; the presence of famous political or cultural leaders; personal qualities of fundraising manager, including the head of the educational institution.

Thus, we can conclude that the need of educational institution to attract multi-channel additional resources for the implementation of joint projects, encourage managers to build partnerships with public organizations, donors, government authorities.

Modern education must be aimed at forming a democratic autlook, civic skills to the younger generation. School as one part of a democratic society is essential for the future, because it determines what democracy be like.

The above system is the driving forces of fundraising prosses, material and social investing in institution development, which is provided by a leader.

Socially active schools are educational instututions, which activity is directed to public development, establishment of relationships and development of partnerships positions to satisfy necessities of school and the community.

The concept of "New school" is just ratified. Space of educational possibilities" determines that public-active school is a central resource in local (incorporated) community and renders to her certain services in accordance with the needs of residents. Establishing that new possibilities in education will be created for the expansion of state-public partnership through new approaches of financing and management. The motion of public-active schools in Ukraine was conceived in 2003, by public organizations (Ukrainian Foundation "Step by Step" with Charles Stewart Mott Foundation and the International Fund "Renaissance" support) wich iniate the program "School as a center of community development". The main program objectives are development of public-active schools that assists to partnership development between school and society; development and realization of partnership programs, the solution and satisfaction of local communities needs; society activity; providing education during the life.

The result of this process is the transformation of services into social and financial investment. In the explanatory dictionary of modern Ukrainian language definition of "service" is understand like:

- it is an action, act that gives a benefit, help another;

- promoting development, raising, dissemination of something;

- work performed to meet someone needs;

- a proposal that can be used.

"Educational services" is a relatively new term in the school management.

In the Law of Ukraine "Social services" are defined as a set of legal, economic, psychological, educational, medical, rehabilitation and other measures directed at specific social groups or individuals who are in crisis and require assistance in order to improve or reproduct their life throught social adaptation and return to normal life [3, p. 11].

In the research we identified governance model of public-active educational institution as a social investment institution. As a result, resources are used not only on the development of the institution, but also in community interests. The school becomes a community center and gets the real help from the local community, commercial organizations and government.

The leader sets the goals, analyzing the possibilities using PEST and SMART technology. Thus, the leader of institution should identify the strengths and weaknesses of the activity, to assess the community cooperation and training needs, to define the general principles of public-active schools and services provided at the school and make the strategy.

Providing different services, schools understand the importance of this work, convinced of their own force and people strength nearby. This work of social-active school is closely associated with democracy, support of healthy relationships between people in the community, as well as relationships between the school and the communityю

The management model as a social investing institution in public-active school is: 
- the synergy of leader competence with public administration and local government institutions in the context of public-active school organization;

- the establishment of council in public-active school;

- the development of NGOs in schools and the democratization of the educational process;

- singling out the mission of public-active schools in development of strategic plans and projects, the implementation of projects strategic management;

- model of teaching staff activity development with focus on meeting the educational needs of community;

- the balance of management decisions in accordance to environment changes and gradual transition from traditional management to the public which is aimed to create a culture of public-active school and manager features (understanding the concept of public-directional control, the introduction of public-directional control, as a kind of adaptive, in culture support of public-active school);

- spread the idea of public- active school.

Therefore, the establishment of educational institution is not only important aspect of its existence and funding, according to the requests and needs of the population, but the defining feature of the community trust to the school head.

Series of researchers and practitioners articles have appeared in scientific and pedagogical periodicals which considered resource support of public schools and professional manager competence in the modern world. There are also different points of views on these issues - some associate the involvement of additional resources to the institution throught the effective operation of parent and guardian councils, the second - with the functioning of Charity Fund, and others - with the fundraising structure creation.

Public Body of the educational institution is Guardian Council, whose functions are defined by the general education regulations. However, it is important to take a notice on its functions under the Law of Ukraine "Education" [4] the first addition, which provides new and considerable authority to Guardian Council compared to other managment education authorities. Guardian Council of educational institution contributes to solving future development challenges, attracting financial resources to ensure its activity and making the control over their use. The formation of Guardian Council, the term of its authority, competence and its functions are defined by the Charter of educational institution. The structure of Guardian Council may not include employees of the institution, while a parents' committee has only the following objectives - protection of children's rights to get quality education and to promote educational institution in the implementation of the educational process. The public functions of government institutions are clearly differentiated, as shown in Tab. 1.

Guardian Council gets almost the most important tasks in attracting financial resources to support the main development directions and to make the control over their use. As follows in the study we offer the experience of progressive international and public non-profit organizations to create endowment funds (relatively new experience appeared in Ukraine in 2009-2010) and by compiling tools endowment fund and the Guardian Council to create an efferctive management innovative model of educational institution, which at the same time will be a type of multi-channel fundraising tool development.

It should be noted that the concept of endowment does not exist yet. There are many varieties of its sources formation. The clear explanation gives Art. 170 Tax Code of Ukraine. It determines endowments as the amount of money or securities, which benefactor contributes in a bank or other financial institution for at least 12 months and can use recived interest and dividends. Aid recipients are not entitled to dispose the principal amount of endowment funds without benefactor consent. In the provisions of this Law does not exist any restrictions of capital minimum, specific goals, or aid recipients, or even the size of reinvestment. But it is excluded all non-financial assets (such as real estate) from the principal amount of endowment funds. 


\begin{tabular}{|c|c|c|c|}
\hline \multicolumn{4}{|c|}{ Education authorities } \\
\hline Advisory/Guardian Council & Head & Teaching Council & Parents' Committee \\
\hline $\begin{array}{l}\text { Guardian Council may } \\
\text { participate in the school work } \\
\text { with advisory capacity, to } \\
\text { make suggestions concerning } \\
\text { manager recolling, provided } \\
\text { by law, the school charter } \\
\text { and the contract. } \\
\text { The order formation of } \\
\text { Guardian Council, the period } \\
\text { of its authority, competence } \\
\text { and its activity are } \\
\text { determined by institution } \\
\text { charter. The structure of } \\
\text { Guardian Council may not } \\
\text { include employees of the } \\
\text { institution. } \\
\text { Founder may delegate the } \\
\text { part of its managment } \\
\text { powers to Guardian Coucil, } \\
\text { including Head appointment } \\
\text { and concluding a contract } \\
\text { with him. } \\
\text { Guardian } \\
\text { contributes to the solution of } \\
\text { development priority tasks, } \\
\text { attracting financial resources } \\
\text { to support its activities and } \\
\text { control of their use, to } \\
\text { effective interaction of school } \\
\text { with public authorities, local } \\
\text { governments, the scientific } \\
\text { community, public -political } \\
\text { organizations and business } \\
\text { entities for the improvement } \\
\text { of educational quality and } \\
\text { competitiveness. }\end{array}$ & $\begin{array}{l}\text { The head of school } \\
\text { is selected by the } \\
\text { competition. The } \\
\text { head concludes a } \\
\text { contract. Qualification } \\
\text { requirements for the } \\
\text { head, the competition } \\
\text { order and the } \\
\text { appointment is } \\
\text { determined by the } \\
\text { Law of Ukraine and } \\
\text { the Charter of an } \\
\text { educational } \\
\text { institution. } \\
\text { Head of school } \\
\text { provides current } \\
\text { management and is } \\
\text { responsible for the } \\
\text { educational, financial } \\
\text { and economic } \\
\text { activities. }\end{array}$ & 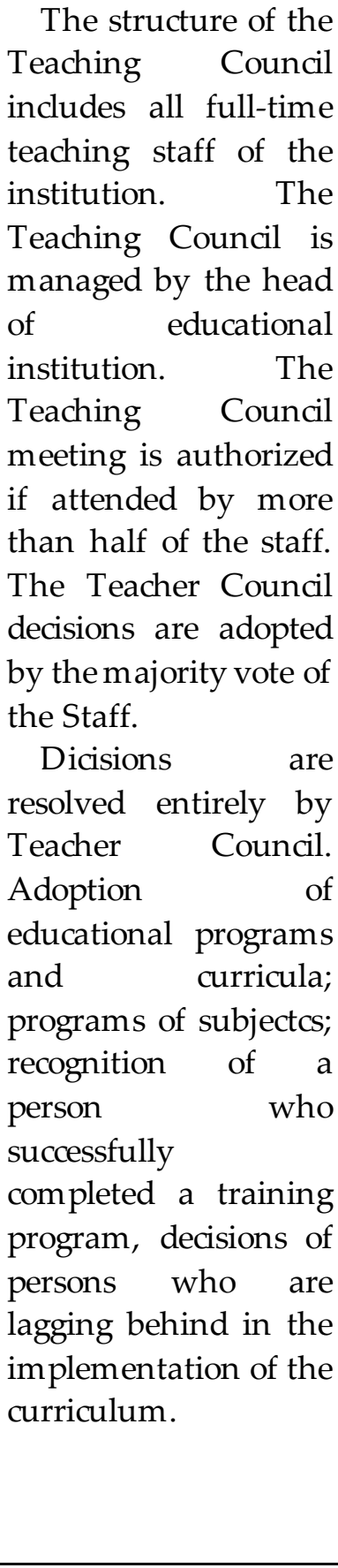 & $\begin{array}{l}\text { The Parent } \\
\text { Committee and } \\
\text { Chairman of the parent } \\
\text { Committee is elected } \\
\text { for one year by the } \\
\text { General parents } \\
\text { meeting, no later than } \\
15 \text { working days after } \\
\text { the start of the school } \\
\text { year. } \\
\text { The main objectives } \\
\text { of the parent } \\
\text { committee are to } \\
\text { protect the children } \\
\text { rights to get quality } \\
\text { education and to } \\
\text { promote school in the } \\
\text { implementation of the } \\
\text { educational process. }\end{array}$ \\
\hline
\end{tabular}

Tab. 1. The functions of public education authorities.

According to the Law - the endowment is the amount of money or securities, which benefactor contributes in a bank or other financial institution, so charity care reciver is entitled to use the interest or dividends in the amount of the endowment [9]. In this case aid recipients are not entitled to dispose the principal amount of endowment funds without benefactor consent. Specific principles regarding endowment funds creations include: Civil Code of Ukraine, the Law of Ukraine "Charity and charitable organizations". General important principles for endowments include the Laws of Ukraine "Securities and stock market", "Collective Investment Institutions" [2, p. 4], "Banks and banking" and instructions of the National Bank of Ukraine from 11.12.2003 year №492 [6, p. 30].

According to Wikipedia endowment fund ((Eng. Endowment [Indarm (ə) nt]) donation, contribution, gift, talent, will, inheritance) - the most transparent charity instrument. According to non- 
profit community organizations it is a trust fund for use in non-commercial purposes. The most popular scope of the target capital funds are traditionally non-profit, health care, social support, education, science, environment, culture, art and more.

Under the Law of Ukraine "Charity and charitable organizations" (second paragraph of Art. 1 and the first part of Art. 2) indicates charity as a voluntary disinterested individuals donation. Charity and charitable activities are based on legality, humanity, common interests and parity of its members, publicity, voluntary and self-government. There is no general definition of endowment, but the Art. 9 containes only the ways of inwestment funds use:

- charity for certain individuals;

- implementation of charity programs;

- joint charity [2].

Summarizing the legal framework of our study we must conclud that the traditional mechanism of the endowment fund is follows:

- endowment fund is filled through charity and it is absolutely intact. We can use only investment profit, exclusively for the needs of the organization;

- endowment delivers the capital to management company and disposes capital for the increase of capital income - interest;

- interest transferred to endowment fund for the intended use.

The objectives are defined by the Charter of the Fund. The Guardian Council coordinates the focus of investments and its priorities.

Endowment benefits :

- fund desposes the capital via professional management company;

- donations are invested in securities and other instruments that can generate additional income. As follows, the fund can not be empty - it can only increase the assets amount due to the interest accumulation;

- endawment fund has untouchable capital, unlike to charity fund, it may use only interest got from the fixed assets;

- fund shall provide transparent reporting concerning the cash flow, which are available to every benefactor;

- fund is established for long term activity;

- management fund income may be used only for the specific purposes.

Summarizing above, the form ation of endowment fund - is the key to financial stability of nonprofit organizations, their independence from the fluctuations and any factors influence. In the study, we propose a model of functions compilation of endowment fund formation with functions of GuardianCouncil which should focus on achieving multiple objectives - implementation of educational programs based on their strategic planning. Among the priorities of this compilation endowment fund and Gaurdian Council, we propose to pay attention to the following:

- endowment tools should be convenient for parents, patrons, benefactors, and for the recipient of such assistance - educational establishment;

- in the cooperation model of endowment fund and Guardian Council we mark only the general rules of their work. We hope hat eventually every educational institution will create its own practice model.

The basic provisions of our position noted the following:

- only benefactors set goals, terms and conditions of endowment income use ;

- at least the half of the annual income must focus on the defined goals. The other part of it are reinvested, to increase endowment revenue;

- Guardian Council is the manager of endowment fund but the beneficiary (educational institution) uses only the revenue;

- change objectives, procedure and terms of endowment use is possible only by common consent of the Guardian Council and benefactors, sponsors, patrons. 
The following circuit system shows the basic terms of endawment fund Guardian Council organization scheme: Guardian Council Endowment fund; Guardian council; Members CHP (parents); Benefactors, patrons; Director of the center; Council members; The head council; Endawment fund council.

Parents and sponsors' contributions are the trust fund for Guardian Council, which is used to ensure the educational process. Assume that Guardian Council endowment fund will be filled by multichannel sources (not prohibited by law) benefactors, members of the educational process and so on. The resourses that we offer to accumulate on the account will be in her trust. Guardian Council is endowed with recieved funds for increasing the income throught the interest accumulating. Interests are transmitted to endowment fund for the intended use. The objectives are defined by the Charter provisions of the institution and Guardian Council and its endowment fund. Guardian Council coordinates prioritize and investments objectives, guided by the priority institution objectives and the results of expert assessments.

Benefits of endowment:

- Guardian Council manages the endowment fund collectively, publicly and openly;

- received funds are immediately spend and invested in securities and other instruments that generate additional income that is accumulated in deposits accounts;

- main endowment fund objective is the accumulation of funds due to the accumulation of interest;

- endowment fund has untouchable capital: he may use only received interest;

- fund shall provide transparent reporting of the cash flow, which is available to every Guardian Council member, benefactor, the participants of the educational process - parents, director;

- endowment fund activities are designed for the long term perspective;

- income may be used only for purposes defined by the Charter institution.

However, the management of endowment fund has positive and negative effects:

- positive - the relative independence of current fundraising, long-term and versatile opportunity planning of assets, significant opportunity to accumulate the required amount through the interest and capital use as a kind of reserve for difficult times;

- negative - the reluctance of donors and parents to contribute, their distrust to offered by us the know-how in terms of unstable socio-political situation.

Therefore, the core competency of Guardian Council is to make clear strategic program objectives of its creation, fundraising mechanism, revenue formation and the use of interest. It should be noted that Guardian Council must be registered as separate legal entity.

We believe that such Guardian Councils will become wow factor and new, effective educational trend. Of course, without a full public component will not be sustainable development of the education system. So we proposed in our study to change the trajectory of Guardian Council "declarative" current model to effective, to be truly effective public-state institution. This can be done only by delegating direct management functions against the state bureaucracy to Guardian Council and awareness that formation of modern model children education of the community is the responsibility of local authorities and the local community.

We think, that the basis of receiving charitable help is formation of Guardian Council endowment fund by its registration as a legal entity that will be able to attract and collect charitable donations and distribute them transparently with the public.

Paid services in the institution should be settled by local administrative documents, as valid legal documents are not provided all points in this process, and the process of money accumulation and store them on deposit account in particular.

Considering the above, note that the new educational legislation of Ukraine, is under public discussion and applicable law regulates social relations in the field of philanthropy (which is fundraising), provides favorable conditions for the form ation and activities of charities foundations and endowment funds through facilitation of charities funds registration, and the introduction of new 
philanthropy instruments provides much more opportunities for development, therefore, the adoption of humanism and democracy in Ukraine.

The study showed charity mechanism registration, as a result of fundraising activity of the school head.

The introduction of fiscal autonomy requires multi-channel financing educational institutions through public participation mechanisms in school development, private investment in education. It is expected during the financial autonomy of the transition from education to finance new principles of its organization, in particular the principle of keeping with the principle of collegiate formation of their budgets and investing in human capital, based on the number of troops and the standard cost of education per student for the level of education; gradual introduction of European principle "money follow the child" through educational voucher system or state contract with schools.

On the basis of stages we can formulate final conclusions of the study:

- educational institutions in Ukraine are in dominant part the nonprofit organizations, and the financial issues are fundamental to modern conditions of gradual changes in the state, depend on the implementation of its capabilities in multi-channel fundraising process;

- the main types of financial support is sponsorship, but in some cases it can have another kind of it;

- it is better to excude fundraising process as a separate tipe of activity in the implementation of fundraising in educational institution;

- diligent planning and preparation of fundraising measures should be implemented beforehand, ranking most important future projects, opportunities, reliability and enormity;

- fundraising leader activity is intended to upgrading and improving existing financing mechanisms and strategic principles of partnerships with donors.

Thus, the result of fundraising activity should be the implementation of specific projects by educational institutions. Fundraising school experts should focus not only on those who finance (donates) money, but also to find new partners who may be interested in school modernization. This partnership could be mutually beneficial as for beneficiaries so for patrons (banefactors). National and international benefactors, patrons, donators have large audience and stakeholders - society, donors, partners, recipients and authorities. Such communication gradually becomes a permanent, continuous and very important process of bilateral (beneficiary and donors) communications with people in need and often depends on the ability of both to find resources to achieve their goals .

As followes the need of the educational institution is to attract additional resources into it encourages its managers to build partnerships with NGOs, donors, philanthropists and government authorities for the implementation of common projects.

Therefore, the modern Ukrainian education needs initiative leaders who are willing to learn and adapt the international experience of fundraising activity with Ukrainian charitable potential for its active implementation. This would allows him to go beyond the narrow confines of the school's daily life, moving to a new stage of development and led the institution in order to keep in step with reforms or even go ahead in rapidly changing social atmosphere. This will create an educational space with high adaptive properties of fleeting reaction to changing conditions. It is important to spread knowledge about nature and benefits of fundraising am ong heads of educational institutions, citizens, awareness through research, trainings, seminars, conferences, newsletter, introducing the subject "Fundraising" in the system of training of educational leaders, etc. Clarifying the concept of "fundraising", identifying problems and prospects of fundraising activities in the educational field of Ukraine will extend the theoretical and practical foundations to conduct effective fundraising cam paign to raise funds for the implementation of socially important projects and researches. With this goal we have formulated the concept of fundraising - as a strategic innovation process of attracting investment for the democratic development of the educational institution.

In modern educational science is marked as not considered the question of conditionality of efficiency of administrative activity of a head to the features to attract additional funds for the development of school, progress of innovative strategies of transparent program-target management. 
The background of head's fundraising competency is characterized by the newest component of managerial competencies, which is related to the requirements of time and changes in the society for the introduction of the system of fundraising in the innovational school management.

The strategy of educational reformation in Ukraine, which is about to start a new Ukrainian school, provides consideration in the process of various factors -political, economic, legal, social, etc. It is also noted that the main direction in development of the state is to reorganize the system of administration, financing and management of education through decentralization, deregulation and implementation of institutional, academic and financial autonomy of schools. It is introduced the principle of subsidiarity by changing approaches to financing - from the principle of retention (financing of walls) to the principle of budgeting formation. Also there will be the introduction of school-based management [3].

The global experience, that Ukraine assimilates, as a result of international technical assistance, contributes to institutional capacity of public authorities and educational institutions established by them, the private sector and civic society on a democratic and self-sufficient social market economy, accelerating international integration. Although Ukraine's strategic goal is to build new civil democratic society, but its success depends on financial resources, because the main purpose of fundraising process in the educational institution is to consolidate all efforts and resources of multichannel investments, where the space of fundraising is the space of goals. Fundraising as a phenomenon defines as the science and art, theory and practice, as a philosophy and psychology, and is identifies with a specific activity of thehead of the educational institution by the control function, which is a method of finding financial resources required for activities of educational institutions including implementation of social, non-profit programs and projects. In other words, a fundraising is the task of educational institution to attract additional funding and other resources to implement specific social project that is the way for changes in educational field.

Modern education must be aimed to the forming of a democratic ideology, civic skills of the younger generation. School, as one of the components of a democratic society, is essential for the future, because it determines what will be the democracy.

Fundraising deals with the solution to these problems since its development in our country and the use of fundraising activities in educational institutions is mandatory and integral process of their effective functioning.

\section{REFERENCES}

[1] Kosytska O.M. (Ed.) Socialy-active school. Type-X.Group “Osnova”, 2014.

[2] The Law of Ukraine "Charity and charitable organizations". July 5, 2012, № 5073-VI. Available at: http://www.rada.gov.ua/.

[3] The Law of Ukraine "Social Services". June 19, 2003, №966-IV. Available at: http://www.rada.gov.ua/.

[4] The Law of Ukraine "Joint Investment Institutions". July 5, 2012, № 5080-VI. Available at: http://www.rada.gov.ua/.

[5] The Law of Ukraine "Banks and Banking". December 7, 2000, № 2121-III. Available at: http://www.rada.gov.ua/.

[6] Instruction of National Bank of Ukraine. December 11, 2003, № 492. Available at: http://zakon2.rada.gov.ua/laws/show/z1172-03.

[7] Robinson K., Aronica L. School of the Future (Transl. from Eng. Leliv H.). Chronicle, Lviv, 2016.

[8] Pidlasyy I.P. Competence and UAH. Type-X.Group "Osnova”, 2014.

[9] Tax Code of Ukraine. December 2, 2010, №2755-VI. Available at: http://zakon2.rada.gov.ua/ laws/show/2755-17.

[10] The project of Ministry of Education and Science of Ukraine. "Ukrainian New School". Available at: http://mon.gov.ua. 
[11] The draft law of Ukraine "Education". Available at: http://w1.c1.rada.gov.ua/pls/zweb2/webproc 4_1?pf3511=58639.

[12] Conceptual moments of project. A Practical Guide. Financial support of European Union, 2008.

[13] Management and development of endowment activity in Ukraine: Toolkit. Analytical work and publication of "Democratization and human rights in Ukraine". UNDP with financial support from the Ministry of Foreign Affairs in Denmark, (2014), 76.

[14] The modern teacher in the student-based model of educational process in the university. Materials from the practical seminar, held at the Vasyl Stefanyk Precarpathian National University, March 3-4, 2016, Publishing Ltd. "Prosvita", Ivano-Frankivsk, 2016, 205 -206.

[15] Cherniavska O.V. Fundraising [text]: student's book. "Centre of educational literature”, K., 2013.

[16] Wawak T. Projakościowa restrukturyzacja zarzadzania w szkolnictwie wyższym. Wstępnetezyprojektu ukraińsko-polskiego EUROUNIVER 2014. Available at: https://tadeusz.wawak.pl.

Address: Galyna Mykhaylyshyn, Vasyl Stefanyk Precarpathian National University, 57, Shevchenko Str., Ivano-Frankivsk, 76018, Ukraine;

Oksana Yakymiv, Vyhoda's Educational Rehabilitation Center, 7, Danyla Halytskoho Str., Vyhoda, Dolyna District, Ivano-Frankivsk Region, 77552, Ukraine.

E-mail: galmuh60@gmail.com.

Received: 20.07.2017; revised: 28.09.2017.

Михайлишин Галина, Якимів Оксана. Актуальні технології професійного менеджменту керівника освітнього закладу. Журнал Прикарпатського університету імені Василя Стефаника, 4 (2) (2017), 104-114.

У статті обгрунтувано сучасні актуальні технології діяльності керівника освітнього закладу. Зокрема, йдеться про фандрайзингову систему як новітній складник управлінських компетентностей, пов' язаний з вимогами часу і змінами орієнтирів суспільства задля впровадження фандрайзинга у інноваційному стратегічному управлінні навчальним закдадом. Розгдянуто загальні теоретичні питання із поширення знань про сутність фандрайзинга в системі освіти та уточнено поняття “фандрайзинг”. Акценти ставдяться на проведенні ефективної фандрайзингової кампанії для залучення коштів на реалізацію соціально значущих та наукових проектів, пошук ресурсів для забезпечення якісного освітнього процесу.

Ключові слова: фандрайзинг, фандрайзингова компетенція, підприємницька ознака, освітня послуга, ендавмент фонд піклувальної ради, бюджетування освітнього закладу, стратегічне управління, фінансова автономія освітнього закладу, специфіка концептів управління. 